\title{
IMPROVING THE METHOD FOR PRODUCING ADSORBENTS FROM AGRO-INDUSTRIAL WASTES
}

\author{
Volodymyr Shmandiy ${ }^{1,}$, Olena Kharlamova ${ }^{1}$, Myroslav Malovanyy ${ }^{2}$, \\ Lilija Bezdeneznych', Tetyana Rigas ${ }^{1}$
}

https://doi.org/10.23939/chcht14.01.102

\begin{abstract}
A multi-stage method for producing an absorbent with increased absorption capacity based on agro-industrial wastes has been proposed. The method includes treatment of raw materials with sulfuric acid, mechanochemical modification, electrostatic separation, and cavitation stage. The expediency of the proposed adsorbent usage in the process of purification of contaminated water from fats, phenols, petroleum products, and heavy metal ions has been proved. The complex application of adsorbents (absorption of gaseous pollutants and wastewater purification) has been tested. Adsorption properties relative to pollutants extraction were found to be better for obtained adsorbents compared with natural absorbents and activated carbon.
\end{abstract}

Keywords: adsorbent, agro-industrial wastes, mechanochemical modification, electrostatic separation, cavitation, ecological safety, purification.

\section{Introduction}

Technogenic impact on the environment, imperfect ecological examination of economic objects, lack of qualified specialists and other factors led to the formation of environmental hazards in the regions [1]. The ways to reduce the level of environmental hazard are: use of renewable energy sources [2], purification of contaminated gaseous media [3] and water [4-8], introduction of environment friendly methods of wastewater sludge [9]. Currently, most of the sorbents used for these purposes are expensive and have complex technologies of obtaining and regenerating [10]. Therefore, the creation of effective sorbents (involving agro-industrial wastes) and their practical application for adsorption purification technologies is one of the priority directions of the technical support of environmental safety

\footnotetext{
${ }^{1}$ Kremenchuk Mykhailo Ostrohradskiy National University, 20, Pershotravneva St., 39600 Kremenchuk, Ukraine sefira@mail.ru

${ }^{2}$ Lviv Polytechnic National University, 12, S.Bandery St., 79013 Lviv, Ukraine (c) Shmandiy V., Kharlamova O., Malovanyy M., Bezdeneznych L., Rigas T., 2020
}

$[11,12]$. The urgency of the research is stipulated by the necessity to find new ways to improve the quality of adsorbents, reduce the anthropogenic load on the water basin and follow the quality standards of hydro ecosystems [13].

The purpose of this work is the scientific and practical substantiation of the improved method for producing an absorbent with increased absorption capacity on the basis of agro-industrial wastes and its use for the purification of wastewater from various types of pollution.

\section{Experimental}

The objects of research were adsorbents derived from plant materials waste. The following agro-industrial wastes were used: buckwheat and oat husks, pods of peas and beans, rapeseed, and corncobs. These wastes contain a significant amount of well-digestible proteins, carbohydrates, fats, organic acids (citric, apple, oxalic acids), as well as vitamins (B1, B2, P, PP, folic acid, carotene). Their composition also includes mineral substances: salts of iron, phosphorus, calcium, and copper. The main organic substances forming the cell membrane are cellulose, lignin and hemicellulose. The fibrous structure of cellulose and lignin is porous one, capable of developing in the process of particles exposure to plastic deformation. multistage.

The proposed method for producing adsorbent is

At the first stage, the plant material was dried to a constant mass at $378 \mathrm{~K}$, while physically bound water was completely removed. The dried raw material was ground, weighed, transferred to the reactor, and sulfuric acid of $65 \mathrm{wt} \%$ concentration was added with the raw material : sulfuric acid ratio $1: 1.5$. The reaction mass was heated under constant stirring for $1.5 \mathrm{~h}$ at $403 \mathrm{~K}$. During heating water vapors, $\mathrm{CO}_{2}$ and $\mathrm{SO}_{2}$ were evolved. The resulting carbonaceous product was washed with distilled water to $\mathrm{pH}=7$ and dried at $378 \mathrm{~K}$.

The second stage of the process is modification of the obtained product during grinding, which is accompanied by mechanical activation. As a result, the 
product undergoes crushing and plastic deformation. During mechanochemical synthesis, under the influence of microstructural clusters aggregation, a developed porous structure is formed in the substance particles. The materials grinding is accompanied by the breakdown of chemical bonds, providing further formation of new bonds, i.e., proceeding of mechanochemical reactions. The mechanical action in the grinding process is impulsive; the initiation of a voltage field and its subsequent relaxation do not occur during the entire residence time of the particles in the reactor, but only at the moment of particles contact and a short time after it.

To study the structure of the resulting adsorbents, we used X-ray diffraction analysis method with the ADP-2.0 diffractometer. Microplots of the samples surface were obtained using an electron microscope EMV-100L (electron-optical magnification is 5500, the total magnification taking into account photo printing is 6700).

Investigations of the adsorbent particles dispersion were carried out using the one-step replicas method. The adsorbent was dispersed and $1 \mathrm{~cm}^{3}$ of acetone was injected into each $30 \mathrm{mg}$ of adsorbent. The mixture was stirred until a suspension was obtained and poured onto a glass surface. The particles of larger sizes precipitated on the glass, and the fine particles were distributed as a thin layer on the liquid surface. Acetone quickly evaporated, so the finedispersed component was distributed uniformly over the glass surface. A sample with a layer of adsorbent was placed in a vacuum installation VUP-4. The carbon film of 50-80 $\mathrm{nm}$ thickness was poured and then separated from the glass in a Petri dish filled with distilled water. "Biolom P-15" microscope was used to detect test particles of the adsorbent and determine their size. The total magnification varied from 202.5 to 2025 .

The mechanical treatment of the adsorbent was carried out using RM-120 mill, in which the crushing cycles of raw material particles with simultaneous action of shear deformations on them were iteratively repeated. The mechanically activated adsorbent, crushed to a fraction of $0.05-1 \mathrm{~mm}$, got into the receiving bin through a discharge grid with holes of different diameters. The total area of adsorbent surface opened by pores, which served as a criterion for the degree of its adsorption capacity, was determined using an electron microscope.

To ensure maximum adsorption capacity, the fourth stage of the adsorbent preparation - cavitation - was realized using a three-bladed impeller of wedge profile with sharp front (angle $38^{\circ}$ ) and blunt back (angle $142^{\circ}$ ) edges. The impeller rotational speed was $4000 \mathrm{rpm}$ and the diameter $-88 \mathrm{~mm}$. The occurrence of cavitation in such a system was confirmed by previous experiments [14, 15]. The formed zones of high and low pressure destroy the product surface, increasing its porosity in quantitative and qualitative terms. The influence of cavitation treatment was studied at the experimental setup (Fig. 1).

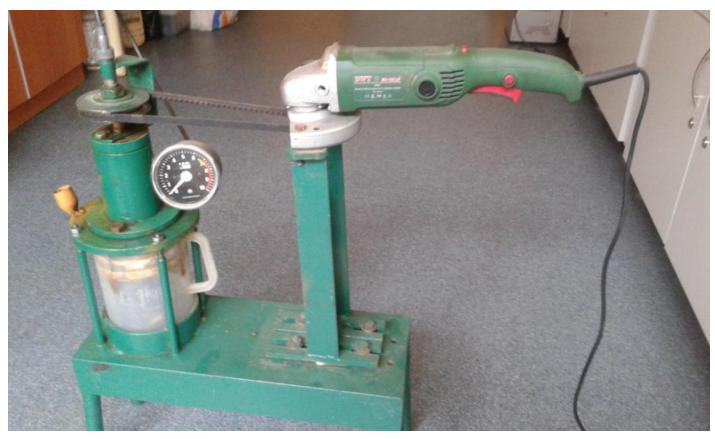

Fig. 1. Setup for studying hydrodynamic cavitation in the process of adsorbent obtaining

Then we prepared the suspension of the agroindustrial wastes processed during the previous stages. The concentration of dry matter in it was $20 \mathrm{~g} / \mathrm{dm}^{3}$. The suspension with mentioned concentration is convenient to introduce into the contaminated liquid medium, which needs to be purified. The cavitator was filled with $1 \mathrm{dm}^{3}$ of the suspension. The sample was withdrawn from the product, treated in a rotary cavitator-stirrer, the operation time of which varied. It was analyzed using an electron microscope.

We have conducted a series of experiments to determine the adsorption capacity of the resulting adsorbents (purification of wastewater from fats, phenols, petroleum products, and heavy metal ions).

Let us consider the determination method of adsorption capacity on the example of petroleum products extraction. A glass flask of $0.2 \mathrm{dm}^{3}$ was loaded with $0.1 \mathrm{dm}^{3}$ of oil-contaminated water and calculated amount of adsorbent. The flask was sealed hermetically, and the adsorption process was carried out under stirring using a shaker for $60 \mathrm{~min}$. The suspension was filtered off. The amount of adsorption $(A)$ and the degree of petroleum products extraction $(S)$ were determined by the formulas:

$$
A=\frac{\left(C_{i n}-C_{r e s}\right) \cdot V_{s}}{m_{a d}}
$$

where $C_{i n}$ - initial concentration of petroleum products in water, $\mathrm{mg} / \mathrm{dm}^{3} ; C_{\text {res }}$ - residual concentration of petroleum products in water, $\mathrm{mg} / \mathrm{dm}^{3} ; V_{s}$ - sample volume, $\mathrm{dm}^{3}$; $m_{a d}-$ adsorbent weight, $\mathrm{g}$.

$$
S=\frac{C_{i n}-C_{r e s}}{C_{i n}} \cdot 100 \%
$$

The content of petroleum products in water was analyzed according to the method [16], which consists in the extraction of petroleum products with an organic solvent followed by the use of IR-photometry. A sample of $1 \mathrm{dm}^{3}$ was placed in the extractor and dried sodium chloride was added till saturation. Then $5 \mathrm{~cm}^{3}$ of sulphuric acid (to decompose salts of naphthenic and sulfonaphthenic acids) and $20 \mathrm{~cm}^{3}$ of ethyl ether were added. Extraction was 
carried out for $5 \mathrm{~min}$ and settled for $10 \mathrm{~min}$. Photometric measurements of solutions were carried out in a cuvette with the optical path length of $5 \mathrm{~cm}$ and the volume of $20 \mathrm{~cm}^{3}$ using IR analyzer ICAN-1.

The amount of phenol in contaminated water was determined via photocolometric method using KFK-2M device.

The total content of ferrum was determined using oxidation-reduction titration with potassium permanganate. The solution was acidified with sulfuric acid and titrated to the final point. Ferrum(II) is oxidized to ferrum(III): $10 \mathrm{FeSO}_{4}+2 \mathrm{KMnO}_{4}+8 \mathrm{H}_{2} \mathrm{SO}_{4}=$ $=5 \mathrm{Fe}_{2}\left(\mathrm{SO}_{4}\right)_{3}+2 \mathrm{MnSO}_{4}+\mathrm{K}_{2} \mathrm{SO}_{4}+8 \mathrm{H}_{2} \mathrm{O}$

If we know the normal concentration of potassium permanganate and its spent volume, we can calculate the amount of ferrum in the investigated solution.

The ferrum content was also determined via photocolorimetric method [17] using ammonium rhodanide (ferrum(III) forms a red compound with rhodanide in the acidic medium). The color intensity is proportional to the ferrum concentration in the solution. The optical density was measured; the correction was made for the optical density of the sample prepared in the same way, but with distilled water and the content of the ferrum was found on the calibration curve. The method allows to detect 0.05 $4 \mathrm{mg}$ of ferrum per $1 \mathrm{dm}^{3}$ of the solution.

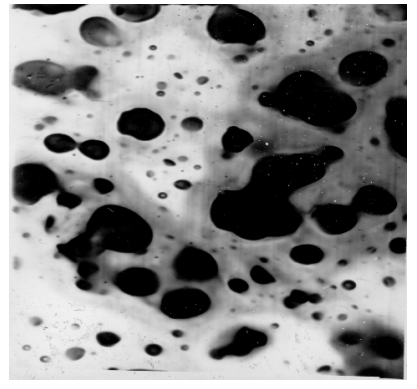

a)

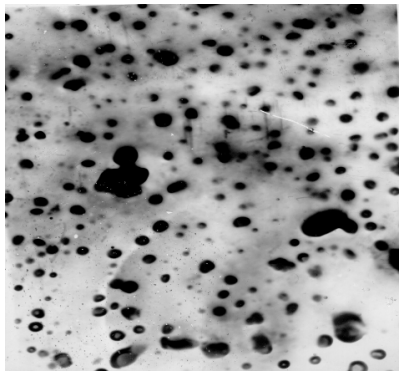

b)
To determine the concentration of zinc we obtained zinc dithizonate of red color. Zinc reacts with ditison at $\mathrm{pH}=$ = 4-7. Cadmium, lead, nickel, cobalt, and other metals also react with ditison in this medium. The method makes it possible to detect $0.005-0.03 \mathrm{mg}$ of zinc per $1 \mathrm{dm}^{3}$ solution.

\section{Results and Discussion}

\subsection{Adsorbent Production}

The experimental results have shown rather close values of characteristic parameters for each type of raw materials. As an example, let us consider the adsorbent obtained from buckwheat husk. We observe the increase in the porousness degree when applying mechanochemical activation (Fig. 2).

Micropores with the diameter of about $0.5 \mathrm{~nm}$, transition pores smaller than $5 \mathrm{~nm}$ and macropores, the size of which varies in the range of 20-50 nm, were determined. The intervals between the particles in the aggregates form a channel system with the characteristic size of $1-2 \mathrm{~nm}$. The dispersion of the mechanically activated adsorbent is $10-20 \mathrm{~nm}$. It should be noted that the product dispersion before mechanoactivation was $50-300 \mathrm{~nm}$, and the pore size varied from 100 to $500 \mathrm{~nm}$.
Fig. 2. SEM images of buckwheat husk based adsorbent (magnification of $6700 \times)$ at different stages of its production: crushing of raw material mechanochemical activation (b)

Table 1 and reaction with sulfuric acid (a) and

Results of experimental studies of mechanically activated adsorbent based on buckwheat husk

\begin{tabular}{|c|c|}
\hline Holes diameter of discharge grid, $\mathrm{mm}$ & Part of the adsorbent surface opened by pores, \% \\
\hline 3.0 & 28 \\
\hline 2.5 & 32 \\
\hline 2.0 & 36 \\
\hline 1.5 & 40 \\
\hline 1.0 & 44 \\
\hline
\end{tabular}

Table 2

Main characteristics of mechanically activated adsorbent based on buckwheat husk

\begin{tabular}{|c|c|c|}
\hline Characteristics & Units & Values \\
\hline Bulk density & $\mathrm{kg} / \mathrm{m}^{3}$ & 490 \\
\hline Moisture content & $\%$ & 2.0 \\
\hline Micropores size & $\mathrm{nm}$ & 0.5 \\
\hline Dispersion & $\mathrm{nm}$ & $10-20$ \\
\hline
\end{tabular}


The determined values of the adsorbent surface opened by pores are given in Table 1 .

Due to the change in the structure of the adsorbent particles, the maximum size of which exceeds $1 \mathrm{~mm}$, a small amount of micropores (Table 1) is formed under the influence of plastic deformation. This leads to the low value of the adsorption capacity. If the particle size is less than $1 \mathrm{~mm}$, the separation of the spent adsorbent from the purified liquid is complicated. Therefore, for the further studies the size of $1 \mathrm{~mm}$ was chosen.

The main characteristics of the mechanically activated adsorbent are given in Table 2.

The results show that the production of an adsorbent from agro-industrial wastes by a grinding process combined with mechanoactivation increases the degree of pores opening and, as a result, the adsorption capacity of the adsorbent. However, this process does not provide necessary homogeneity of the adsorbent granulometric composition. In addition, it is complicated by changing the equipment if we change the raw material. The problem was solved by the implementation of the third stage of the adsorbent production - electrostatic separation of a powder obtained after mechanoactivation. The process is demonstrated in Fig. 3.

Using a screw dispenser 2 the powder of raw material is fed from bin 1 to a continuous knife mill 3 , in which the cycles of crushing raw material particles with simultaneous action of shear deformation on them are iteratively repeated. The crushed product enters the

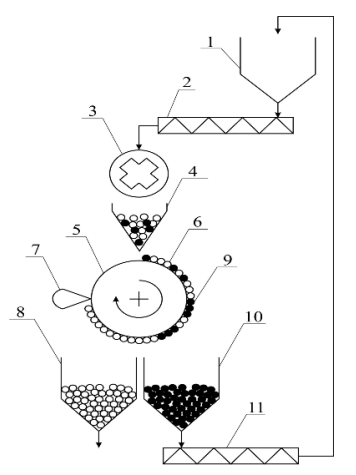

Fig. 3. Block diagram of an improved method for obtaining adsorbent using electrostatic separation

The results of the adsorbents application for the removal of pollutants from water are given below. We compared sorption ability of different adsorbents at the same granulometric composition under the same hydrodynamic conditions. As an example, let us consider fat-containing rinsing water from the oil-refining plant. For the investigations we simulated waste water with fats concentration of $0.2 \mathrm{~g} / \mathrm{dm}^{3}$. The results are shown in Fig. 5 . The purification efficiency monotonically increases in time, reaching saturation $(98.5 \%)$ in $20 \mathrm{~min}$. For intermediate measuring bin 4 and then the drum of the electrostatic separator 5 , where the electrostatic field holds the particles 6 of the selected granulometric composition on the drum surface. The particles through the scrapper 7 enter the receiving bin 8 . The product particles 9 , which do not correspond to a given separation level, are collected in the intermediate bin 10 , and then are fed to the bin 1 for remechanoactivation using screw 11 . The technological process is repeated until the adsorbent with a given homogeneous granulometric composition is obtained.

The separation level is determined depending on the type of raw material based on the previous results regarding the adsorbent structure.

The microstructure of the adsorbent surface after its additional treatment in the cavitation field is shown in Fig. 4. The time of $10 \mathrm{~min}$ for the product treatment in the cavitation field was found to be optimal. During the treatment for less than $10 \mathrm{~min}$, the adsorbent surface is not fully opened. The results also show that the adsorbent particles differ in size and shape. There are micropores with an average size of $0.5-5.0 \mathrm{~nm}$ and macropores with $5-20 \mathrm{~nm}$; the sorbent dispersion is $10 \mathrm{~nm}$. When comparing these results with the data given in Fig. 1, we observe the increase in the degree of pores opening, followed by the increase in adsorption capacity of the adsorbent. Moreover, the application of agro-industrial wastes for the adsorbent production reduces the price of the technological process (in comparison with the use of natural raw materials) and increases the efficiency of the method as a whole.

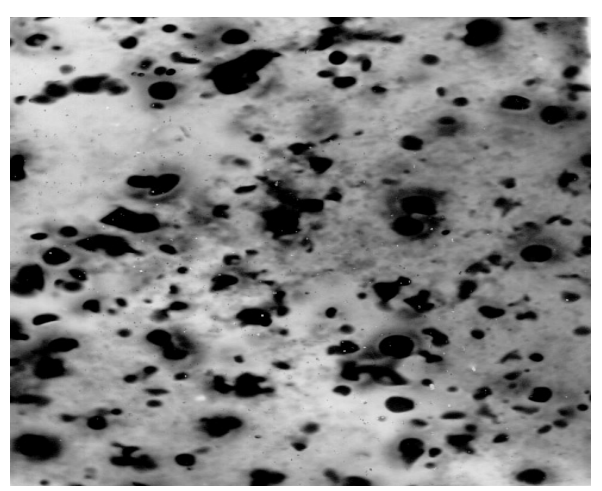

Fig. 4. Micrograph of the adsorbent surface after additional treatment in the cavitation field. Magnification of $6700 \times$

comparison, a similar experiment was conducted with a standard adsorbent (activated carbon). We observe a qualitatively similar dependence on time, and maximum absorption is $97 \%$. So, the investigated adsorbent has the same efficiency as a standard one. This confirms the expediency of the proposed adsorbent for purification of rinsing water contaminated by fats.

To purify wastewater containing phenol and its derivatives we used adsorbent based on oat husks and compared it with natural adsorbents (clay, silica gel) and 
activated carbon. The results of experiments indicate that the adsorbent obtained by us has an adsorption capacity higher than that of natural adsorbents and activated carbon [9] (Fig. 6).

The study on the wastewater purification from petroleum products by the proposed adsorbents was carried out on an example of lubricant. The used model wastewater has $200 \mathrm{mg} / \mathrm{m}^{3}$ of the lubricant. The used adsorbent of different granulometric composition was based on buckwheat husk. The results are shown in Fig. 7.

One can see from Fig. 7, that the decrease in the granulometric composition of the adsorbent improves the purification efficiency. The fraction of $0.1-1 \mathrm{~mm}$ was found to be the most effective, because it is rather difficult to separate the fine dispersion fraction of the adsorbent. The process time is $60 \mathrm{~min}$.

Fig. 8 shows the adsorption capacity of the adsorbent based on buckwheat husk and used to purify wastewater from heavy metal ions. We simulated model waters with iron concentration of $15 \mathrm{~g} / \mathrm{m}^{3}$ and zinc concentration of $10 \mathrm{~g} / \mathrm{m}^{3}$. In both cases, under alkaline conditions $(\mathrm{pH}=9)$ the adsorption capacity is maximum. This occurs due to the formation of hydroxides that remain in the adsorbent pores and do not require special deposition.

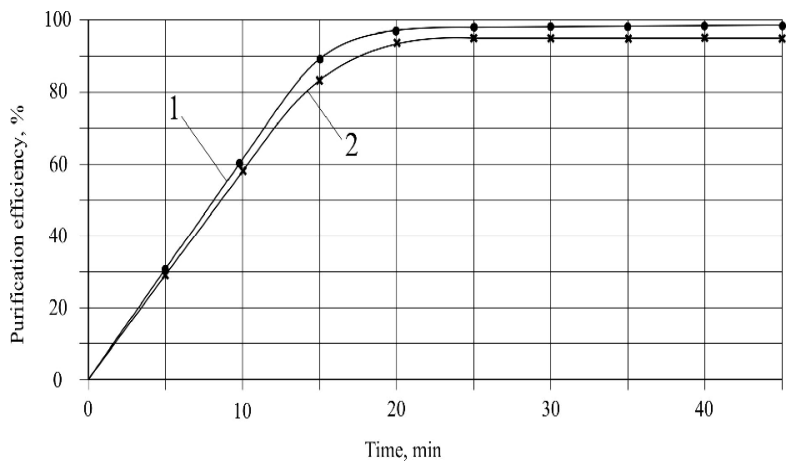

Fig. 5. Results of fat-containing water purification by the adsorbent on the basis of agro-industrial waste (bean pods) (1) and reference adsorbent (2)

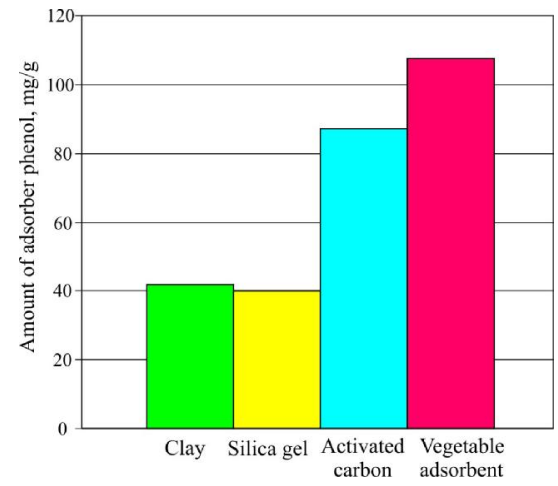

Fig. 6. Results of the phenol adsorption by various adsorbents

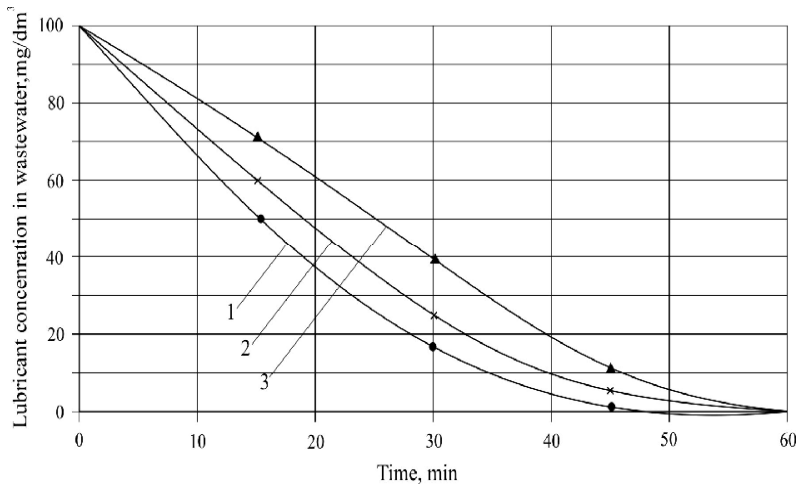

Fig. 7. Time behavior of the lubricant concentration in contaminated water using adsorbents of different granulometric composition (mm): 0.03-0.01 (1); 0.1-1.0 (2) and 1.0-3.0 (3)

The comparison of the efficiency of the proposed adsorbent was carried out in relation to the activated carbon. The results shown in Fig. 9 indicate the expediency of using the resulting adsorbent.

Therefore, the obtained results indicate the expediency of the proposed adsorbent in the process of contaminated water purification from fats, phenols, petroleum products, and heavy metal ions. Spent adsorbents should be used as a fuel at power plants.

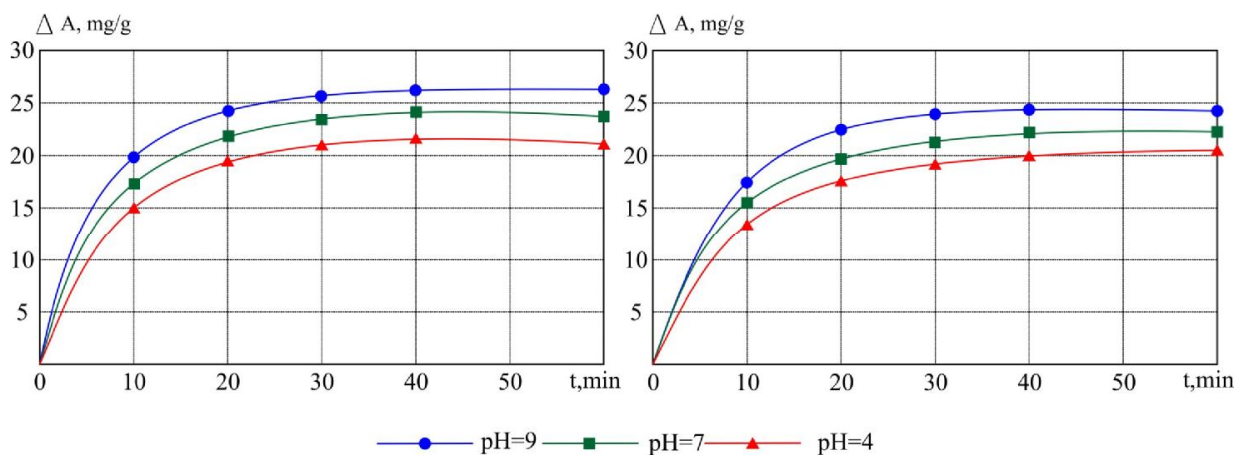

Fig. 8. Dependence of iron (a) and zinc (b) ions adsorption from the model wastewater on the time with different acidity of the medium 
Adsorption of gaseous pollutants ( $\mathrm{g} / \mathrm{min})$

\begin{tabular}{|c|c|c|c|}
\hline \multirow{2}{*}{ Pollutants source } & \multicolumn{3}{|c|}{ Adsorbent based on } \\
\cline { 2 - 4 } & Sunflower husk & Sunflower stems & Activated carbon \\
\hline Motor engine test stand & 80 & 77 & 75 \\
\hline Boiler-house in hospital & 73 & 72 & 69 \\
\hline
\end{tabular}

Table 4

Adsorption of pollutants from wastewater (g/kg)

\begin{tabular}{|c|c|c|c|}
\hline \multirow{2}{*}{ Heavy metals } & \multicolumn{3}{|c|}{ Adsorbent based on } \\
\cline { 2 - 4 } & Sunflower husk & Sunflower stems & Activated carbon \\
\hline Chrome(III) & 79 & 73 & 68 \\
\hline Nickel(II) & 80 & 66 & 68 \\
\hline
\end{tabular}

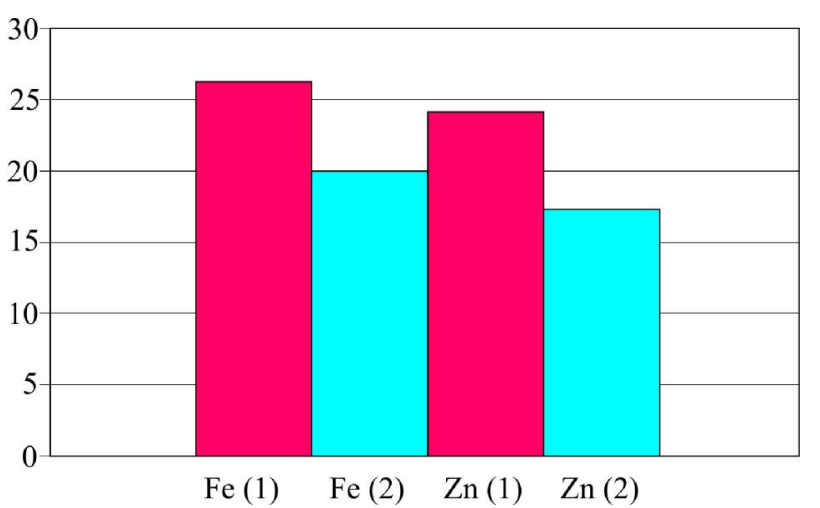

Fig. 9. Maximum adsorption values of the adsorbent based on buckwheat husk (1) and activated carbon (2)

We also carried out a comprehensive study on the use of adsorbents for the absorption of gaseous pollutants (total hydrocarbons and sulfur oxides) (Table 3) and for wastewater purification (Table 4).

The process of gaseous pollutants adsorption was studied for a boiler-house in hospital, which operates on high-sulfur fuel oil, as well as for a motor engine test stand. Adsorbent was used to remove heavy metal ions from wastewater of galvanic production.

In both cases (Tables 3 and 4), the adsorption properties of the investigated adsorbents are commensurable with those of standard (activated carbon). Since the spent adsorbent contains a significant amount of combustible substances, it is proposed to be used as an additive to produce ceramic bricks.

The following results can be achieved by implementing the proposed schemes:

- reduction of environmental hazard level by preventing the ingress of harmful substances contained in wastes into soil, water-bearing horizons and ponds;

- reduction of environmental hazard level due to landscapes transformation by returning territories allocated for the storage of wastes to the economic use;
- weakening of distant manifestations of hazard in the regions where natural raw materials are concentrated due to reduction of production volumes by their replacement by wastes.

\section{Conclusions}

We consider the process of obtaining adsorbents as an element of environmental safety management, since the utilization of wastes in this process reduces the probability of the environmental hazard associated with environment pollution with harmful substances contained in wastes. We grounded and experimentally proved that adsorbents based on agro-industrial wastes increase the ecological safety. We also confirmed the industrial suitability of the proposed method, its efficiency and successful commercialization.

\section{References}

[1] Shmandiy V., Bezdeneznych L., Kharlamova E.: Hihiena i Sanitaria, 2012, 6, 2.

[2] Mandryk O., Arkhypova L., Pobigun O., Maniuk O.: Int. Conf. on Innovative Ideas in Science (IIS2015)12-13, Romania, Baia Mare 2015, 144. http://iopscience.iop.org/issue/1757-899X/144/1 「3] Hurets L., Kozyi I., Pliatsuk L.: Gazoochistnoe Oborudovanie dlya Kompleksnoy Ochistki Gazov. Lambert Academic Publishing 2014.

[4] Malovanyy A., Plaza E., Trela J., Malovanyy M.: Water Sci. Technol., 2014, 70, 144. https:doi.org/10.2166/wst.2014.208

$\lceil 5\rceil$ Kulikova D., Pavlychenko A.: Sci. Bull. Nat. Mining Univ., 2016, 4, 62 .

[6] Malovanyy M., Zhuk V., Sliusar V. et al.: East Eur. J. Adv. Technol., 2018, 1(10), 23. https://doi.org/10.15587/17294061.2018.122425

[7] Malovanyy M., Shandrovych V., Malovanyy A. et al.: J. Chem., 2016, 2016, 9. https://doi.org/10.1155/2016/6874806

[8] Kolesnik V., Kulikova D., Pavlichenko A.: Sci. Bull. Nat. Mining Univ., 2016, 6, 120.

[9] Pliatsuk L., Chernish E.: Environ. Protect. Eng., 2013, 39, 101. https://doi.org/10.5277/epe130308 
[10] Toles C.: Bioresource Technol., 2000, 75, 197. https://doi.org/10.1016/S0960-8524(00)00058-4

[11] Danchenko Y., Andronov V., Kariev A. et al.: East. Eur. J. Adv. Technol., 2017, 5(12), 20. https://doi.org/10.15587/17294061.2017.111350

[12] Malyovanyy M., Sakalova G., Chornomaz N. et al.: Chem. Chem. Techol., 2013, 7, 355.

https://doi.org/10.23939/chcht07.03.355

[13] Adamenko Y., Arkhypova L., Mandryk O.: Hydrobiolog. J., 2017, 2, 50. https://doi.org/10.1615/HydrobJ.v53.i2.50

[14] Matsuska O., Paranyak R.: Nauk. Visnyk Lviv Nats. Univ. Veterinar. Mediciny i Biotechn., 2008, 4, 181.

[15] Vitenko T., Gumnitsky Ya.: J. Water Chem. Technol., 2007, 29, 231. https://doi.org/10.3103/S1063455X07050037

[16] Kyrychenko O., Malovanyy M., Polyuzhyn I.: Visnyk Ukr. Nats. Lisotechn. Univ., 2009, 19, 324.

[17] Rahman M., Assadullah M., Rahman A. et al.: J. Surface Sci. Technol., 2006, 22, 133. https://doi.org/10.18311/jsst/2006/1963

Received: April 13, 2018 / Revised: July 04, 2018 / Accepted: September 22, 2018

\section{УДОСКОНАЛЕННЯ СПОСОБУ ОТРИМАННЯ \\ АДСОРБЕНТІВ ІЗ ВІДХОДІВ АГРОПРОМИСЛОВОГО КОМПЛЕКСУ}

Анотація. Запропоновано багатостадійний спосіб отримання адсорбенту підвищеної поглинальної здатності на основі відходів агропромислового комплексу, який включає оброблення сировини сульфатною кислотою, механохімічне модифікування, електростатичну сепарацію та стадію кавітаиії. 3 а результатами експериментальних досліджень доведена доиільність застосування запропонованого адсорбенту в процесі очищення забруднених водних середовищ від жирів, фенолів, нафтопродуктів та йонів важких металів. Апробовано комплексне застосування адсорбентів: поглинання газоподібних икідливих речовин та очищення стічних вод. Встановлено, щуо адсорбиійні властивості отриманих адсорбентів у відношенні вилучення забруднювачів більше виражені, у порівнянні 3 природними абсорбентами та активованим вугіллям.

Ключові слова: адсорбент, відходи агропромислового комплексу, механохімічне модифікування, електростатична сепарачія, кавітація, екологічна безпека, очищення. 